CLINICAL STUDY

\title{
Association of CD40 and thyroglobulin genes with later-onset Graves' disease in Taiwanese patients
}

\author{
Jeng-Yueh Hsiao ${ }^{1}$, Ming-Chia Hsieh ${ }^{1}$, Cheng-Ting Hsiao ${ }^{2}$, Hsu-Huei Weng ${ }^{3,4,5}$ and Der-Shin $\mathrm{Ke}^{6}$ \\ ${ }^{1}$ Division of Endocrinology and Metabolism, Department of Internal Medicine, Kaohsiung Medical University Hospital, Kaohsiung 807, Taiwan, ROC, \\ ${ }^{2}$ Department of Emergency Medicine, Chang Gung Memorial Hospital, Chang Gung University College of Medicine, Chiayi 613, Taiwan, ROC, \\ ${ }^{3}$ Department of Diagnostic Radiology, Chang Gung Memorial Hospital, Chiayi 613, Taiwan, ROC, ${ }^{4}$ Department of Respiratory Care, Chang Gung Institute \\ of Technology, Chiayi 613, Taiwan, ROC, ${ }^{5}$ Graduate Institute of Occupational Safety and Health, College of Health Sciences, Kaohsiung Medical University, \\ Kaohsiung 807, Taiwan, ROC and ${ }^{6}$ Division of Neurology Medicine, Department of Internal Medicine, Chi-Mei Medical Center, Tainan 710, Taiwan, ROC \\ (Correspondence should be addressed to D-S Ke who is now at Department of Endocrinology and Metabolism, Chung-Ho Memorial Hospital, Kaohsiung \\ Medical University, 100 Shin-Chuan 1st Road, Kaohsiung 807, Taiwan, ROC; Email: dershin@mail.cmu.edu.tw)
}

\begin{abstract}
Objective: Graves' disease (GD) is known to be associated with thyroglobulin (TG) and CD4O genes. Therefore, we decided to investigate the relationship of age at onset of GD with CD4O and TG gene susceptibilities in a Taiwanese population.

Design and method: We analyzed the association of TG and CD4O polymorphisms with age at onset of GD in Taiwanese patients. We stratified patients into those with early onset ( $<40$ years; $30.3 \pm 4.8$ years; $n=135$ ) and later onset ( $\geq 40$ years; $52.3 \pm 6.3$ years; $n=80$ ) and compared the results with those of 141 normal controls.

Results: We found a significant statistical difference in the T/T genotype frequency of E33 single nucleotide polymorphism (SNP) and G/G genotype frequency of E12 SNP when compared with the control group $(P<0.001)$. In addition, the frequencies of the T allele and TT genotype of the CD4O SNP were found to be significantly increased in GD patients who developed GD aged over 40 years than those below 40 years (allele: $\chi^{2}=5.299, P=0.021, \mathrm{OR}=1.597$; genotype: $\chi^{2}=6.168, P=0.046$ ). By contrast, the frequencies of genotypes in the TG gene E10, E12, and E33 SNPs were not found to be significantly different in GD patients who developed GD when aged over 40 years when compared with those aged below 40 years. Conclusions: These data suggest that the T/T genotype and $\mathrm{T}$ allele in the $C D 4 O$ gene are more likely to be associated with late-onset GD in Taiwanese patients.
\end{abstract}

European Journal of Endocrinology 159 617-621

\section{Introduction}

Graves' disease (GD) is an autoimmune lymphocytemediated disease characterized by clinical hyperthyroidism with diffuse goiter, ophthalmopathy $(1,2)$, and the presence of anti-thyroid-stimulating hormone (TSH) receptor antibodies (3), although both environmental and genetic factors appear to play a role in disease susceptibility (4). Although the precise mechanism for the pathogenesis of this disorder is not fully understood, the CD4O and thyroglobulin (TG) genes have been considered to be major genetic factors involved in the development of GD.

An association of the $\mathrm{C} / \mathrm{T}$ polymorphism in the $\mathrm{CD} 40$ gene with GD in Caucasians (5) and Koreans (6) has recently been established; however, the association could not be confirmed in UK Caucasians $(7,8)$. Moreover, there is well-established evidence concerning the association of $T G$ gene polymorphisms with GD in Taiwanese (9) and Caucasians (10).

A previous study revealed that different allelic human leukocyte antigen (HLA) associations have been reported in patients with early onset of GD than those from patients with later onset of GD in a Japanese population (11). In addition, another study suggested that the relative risk for DRB1*0301 was higher for juvenile patients than for adult patients with GD in Caucasian patients (12). Therefore, we decided to investigate the relationship of age at onset of GD with $C D 4 O$ and $T G$ gene susceptibilities in a Taiwanese population. This study investigated the association of $C D 4 O$ and $T G$ gene polymorphisms with patients who developed GD aged over 40 years and those below 40 years and compared the results with normal controls.

\section{Subject and methods}

\section{Subjects}

We enrolled 215 Chinese patients with GD (151 females and 64 males; age, $40 \pm 13$ years) from the Endocrine Clinic and 141 healthy controls (84 females and 
57 males; age, $41 \pm 12$ years) from the Health Care Center of Kaohsiung Medical University Hospital. GD was diagnosed based on clinical and laboratory evidence of hyperthyroidism and diffuse goiter, supported by the presence of TSH-receptor antibodies, or exophthalmos. We excluded patients with a history of radioiodine therapy or previous thyroid surgery. The controls were healthy subjects with no clinical evidence or family history of any autoimmune disease. They were in the euthyroid state according to the laboratory tests and had no obvious goiter, as determined by an experienced research staff member. The patients and control subjects were recruited after giving fully informed written consent. The clinical trial was registered with the Institutional Review Board of Kaohsiung Medical University Hospital, Taiwan, ROC (KMUH-IRB-960130).

\section{Genotypes}

DNA was extracted from peripheral blood leukocytes using a DNA extraction kit (RadioMed, Tyngsboro, MA, USA). The TG single nucleotide polymorphisms (SNPs) (E10, E12, and E33) at the TG gene were genotyped by the PCR-restriction fragment length polymorphism method, using the primers listed in Table 1. The CD4O SNP at the CD4O gene was digested using the PCRrestriction fragment length polymorphism method; the primers used were: forward $C D 40$ gene 5'CCTCTTCCCCGAAGTCTTCC- $3^{\prime}$ and reverse CD4O gene 5'-GAAACTCCTGCGCGGTGAAT-3'.

PCR was carried out in a $25 \mu \mathrm{l}$ mixed solution, containing $0.2 \mu \mathrm{g}$ genomic DNA (from blood leukocytes), $0.4 \mathrm{mmol} / \mathrm{l}$ primers, $0.2 \mathrm{mmol} / \mathrm{l}$ each of deoxyATP, -GTP, -CTP, and -TTP, $2 \mathrm{mmol} \mathrm{MgCl}_{2}, 0.5 \mathrm{U}$ Taq DNA polymerase, $50 \mathrm{mmol} / \mathrm{l} \mathrm{KCl}, 10 \mathrm{mmol} / \mathrm{l}$ Tris-HCl (pH 8.3). PCR involved an initial denaturation step for 5 min at $95^{\circ} \mathrm{C}, 35$ cycles of denaturation for $30 \mathrm{~s}$ at $95{ }^{\circ} \mathrm{C}$, primer annealing for $30 \mathrm{~s}$ at $56^{\circ} \mathrm{C}$, and primer extension for $60 \mathrm{~s}$ at $72{ }^{\circ} \mathrm{C}$, followed by a final extension step for $5 \mathrm{~min}$ at $72{ }^{\circ} \mathrm{C}$ in a thermal-cycler (Gene Amp PCR System 9600; Perkin-Elmer, Foster City, CA, USA). The amplified products of the TG SNPs (E10, E12, and E33) were digested with the restriction enzymes, Bpu10I, BsaAI, and Hpy99I at $37{ }^{\circ} \mathrm{C}$ for $4 \mathrm{~h}$ (New
England BioLabs, Hitchin, UK; Table 1); the CD4O SNP amplified products were digested with the restriction enzyme StyI at $37^{\circ} \mathrm{C}$ for $4 \mathrm{~h}$ (New England BioLabs) and analyzed on $3 \%$ agarose gel.

\section{Laboratory test}

Serum $\mathrm{T}_{4}, \mathrm{~T}_{3}$ and TSH levels were measured by RIA. TSH levels were measured using a one step sandwich assay with a normal range of $0.25-4.0 \mu \mathrm{U} / \mathrm{ml}(0.25-$ $4.0 \mathrm{mU} /$ liter; RIA-gnosthTSH; CIS Bio International, Gif-Sur-Yvette, Cedex, France). Serum $\mathrm{T}_{4}$ and $\mathrm{T}_{3}$ concentrations were measured using commercial kits (Abbott), with the normal ranges being 12.0$27.5 \mathrm{pmol} / \mathrm{l}$ and $1.31-2.74 \mathrm{nmol} / \mathrm{l}$ respectively. TSH receptor antibody was measured by radioreceptor assay with a commercial kit (Dia Sorin Inc., Stillwater, MN, USA). The cut-off value for TRAb was $10 \%$.

\section{Statistical analysis}

The laboratory data were expressed as means \pm s.D.

Statistical analysis was performed using the Statistical Package for the Social Science program (SPSS for Windows, Version 10.0; SPSS, Chicago, IL, USA). Allele frequencies were estimated by direct gene counting. Observed numbers of each genotype were compared with those expected for Hardy-Weinberg equilibrium using the $\chi^{2}$ test. In this study, a two-tailed $P$-value less than 0.05 was considered significant.

\section{Results}

\section{Association of TG and CD40 gene polymorph- isms with susceptibility to GD}

The genotype and allele frequencies at E10 SNP158, E12 SNP, E33 SNP, and CD4O SNP in GD patients were compared with those of the controls. The distribution of the genotypes was compatible with that of HardyWeinberg equilibrium in both the control and patient groups. There was a significant statistical difference in the T/T genotype of E33 SNP and G/G genotype of E12 SNP

Table 1 SNPs in the TG gene.

\begin{tabular}{|c|c|c|c|c|c|c|}
\hline SNP & $\begin{array}{l}\text { Location } \\
\text { in } T G \text { gene }\end{array}$ & $\begin{array}{l}\text { Base } \\
\text { change }\end{array}$ & Primers $^{a}$ & $\begin{array}{c}\text { PCR } \\
\text { product } \\
\text { size (bp) }\end{array}$ & $\begin{array}{c}\text { RFLP } \\
\text { enzyme }\end{array}$ & $\begin{array}{c}\text { RFLP } \\
\text { product } \\
\text { size (bp) }\end{array}$ \\
\hline E10 SNP158 & Exon 10 & $\mathrm{~T} / \mathrm{C}$ & $\begin{array}{l}\text { F: CACCTGCTCATTGTTCCTCC } \\
\text { R: TCTTCACTAGCAGCTTGGCA }\end{array}$ & 264 & Bpu10I & $\begin{array}{l}\text { TT: } 82,182 \\
\text { CC: } 264\end{array}$ \\
\hline E12 SNP & Exon 12 & $A / G$ & $\begin{array}{l}\text { F: CAGAGCCCACACAGAGCAGG } \\
\text { R: AAAAAGGGGTGTCACTTGGC }\end{array}$ & 241 & BsaAl & $\begin{array}{l}\text { GG: } 105,136 \\
\text { AA: } 241\end{array}$ \\
\hline E33 SNP & Exon 33 & $\mathrm{C} / \mathrm{T}$ & $\begin{array}{l}\text { F: ATATTGACCAAAGCACCCCC } \\
\text { R: ATTAGCCAGTTGCCCTCTCC }\end{array}$ & 375 & Hрy99I & $\begin{array}{l}\text { CC: } 167,208 \\
\text { TT: } 375\end{array}$ \\
\hline
\end{tabular}

${ }^{\mathrm{a}} \mathrm{F}$, forward primer sequence; $\mathrm{R}$, reverse primer sequence. 
when compared with the control group $(P<0.001$; Table 2). The genotype and allele frequency at the $C D 4 O$ SNP in GD patients were not found to be significantly different to those of the controls by the $\chi^{2}$ test (genotype: $\chi^{2}=0.084, P=0.959$; allele: $\chi^{2}=0.032, P=0.859$; Table 2).

\section{Association of the CD40 gene polymorphism with the age of the onset of Graves' disease}

There were two peaks in the age of onset of GD (Fig. 1). The frequencies of the T allele and TT genotype at the CD4O SNP were found to be significantly increased in GD patients who developed GD aged over 40 years than those aged below 40 years. (allele: $\chi^{2}=5.299, P=0.021$, $\mathrm{OR}=1.597$; genotype: $\chi^{2}=6.168, P=0.046$; TT $+\mathrm{CT}$ versus $C C, \chi^{2}=5.007, P=0.025$, OR =2.000; Table 3).

\section{Association of the TG gene polymorphism with the age of the onset of Graves' disease}

There was no significant difference in the TT genotype frequency of the $T G$ gene E10 polymorphism between the patients who developed GD aged above 40 years and those aged below 40 years (genotype: $\chi^{2}=2.972$, $P=0.226$; Table 4). Similarly, in the TG gene E12 and E33 polymorphisms, no significant differences were found between the patients who developed GD aged over 40 years and those below 40 years (data not shown).

Table 2 Allele and genotype frequencies of the $T G$ and $C D 40$ SNPs in patients with Graves' disease (GD) and control subjects.

\begin{tabular}{|c|c|c|c|c|}
\hline $\begin{array}{l}\text { Alleles/ } \\
\text { genotype }\end{array}$ & $\begin{array}{l}\text { Normal } \\
\text { control } \\
\text { group } \\
(N=141)\end{array}$ & $\begin{array}{c}\text { Graves' } \\
\text { disease } \\
\text { group } \\
(N=215)\end{array}$ & $\chi^{2}$ & $P$ value \\
\hline \multicolumn{5}{|c|}{ TG E10 SNP158 } \\
\hline $\mathrm{T}$ & $113(40.1 \%)$ & $162(37.7 \%)$ & & \\
\hline C & 169 (59.9\%) & $268(62.3 \%)$ & 0.413 & 0.521 \\
\hline TT & $16(11.3 \%)$ & $18(8.40 \%)$ & & \\
\hline $\mathrm{TC}$ & $81(57.4 \%)$ & $126(58.6 \%)$ & & \\
\hline $\mathrm{CC}$ & 44 (31.2\%) & 71 (33.0\%) & 0.896 & 0.639 \\
\hline \multicolumn{5}{|c|}{ TG E12 SNP } \\
\hline G & $108(38.3 \%)$ & 135 (31.4\%) & & \\
\hline A & $174(61.7 \%)$ & $295(68.6 \%)$ & 3.609 & 0.057 \\
\hline GG & $15(10.6 \%)$ & $6(2.80 \%)$ & & \\
\hline GA & $78(55.3 \%)$ & $123(57.2 \%)$ & & \\
\hline AA & $48(34.1 \%)$ & $86(40.0 \%)$ & 9.747 & 0.008 \\
\hline \multicolumn{5}{|c|}{ TG E33 SNP } \\
\hline $\mathrm{C}$ & 112 (39.7\%) & 107 (24.9\%) & & \\
\hline $\mathrm{T}$ & $170(60.3 \%)$ & $323(75.1 \%)$ & 17.593 & $<0.001$ \\
\hline $\mathrm{CC}$ & $18(12.8 \%)$ & $9(4.20 \%)$ & & \\
\hline CT & 76 (53.9\%) & 89 (41.4\%) & & \\
\hline TT & 47 (33.3\%) & 117 (54.4\%) & 19.357 & $<0.001$ \\
\hline \multicolumn{5}{|l|}{ CD40 SNP } \\
\hline $\mathrm{T}$ & $107(37.9 \%)$ & 166 (38.6\%) & & \\
\hline C & $175(62.1 \%)$ & $264(61.4 \%)$ & 0.032 & 0.859 \\
\hline TT & $15(10.6 \%)$ & $25(11.6 \%)$ & & \\
\hline $\mathrm{CT}$ & $77(54.6 \%)$ & $116(54.0 \%)$ & & \\
\hline $\mathrm{CC}$ & 49 (34.8\%) & 74 (34.4\%) & 0.084 & 0.959 \\
\hline
\end{tabular}

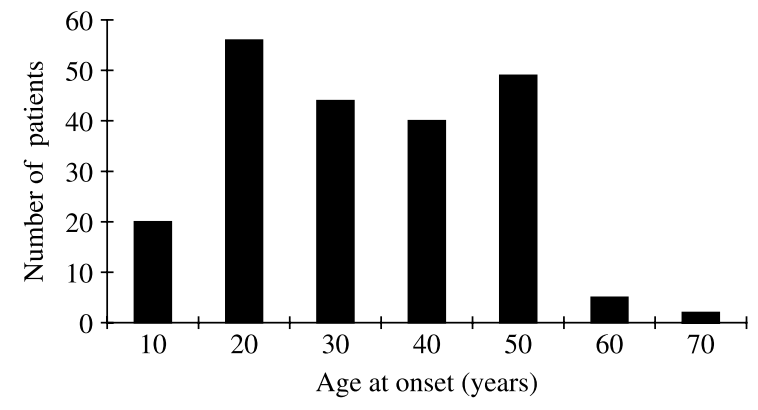

Figure 1 Distribution of age at onset of Graves' disease.

\section{Interaction between the TG exon 10 SNP and the CD40 SNP for the age of the onset of Graves' disease}

We analyzed for gene-gene interaction between the associated TG and CD4O SNPs. Case control association analysis of the TG SNPs in combination with the CD4O SNPs showed no evidence of an interaction between CD4O and TG exon 10 SNP.

\section{Discussion}

This study had three major findings. Firstly, we found a significant statistical difference in the T/T genotype of E33 SNP and the G/G genotype of E12 SNP when compared with the control group. Secondly, we found that the frequencies of the T allele and TT genotype at the CD4O SNP were found to be significantly increased in GD patients who developed GD aged above 40 years than those aged below 40 years. Thirdly, no significant difference was found in the frequencies of genotype in the TG gene E10, E12 and E33 SNPs between GD patients who developed GD aged above 10 years and those below 40 years.

The prevalence of autoimmune thyroid diseases (AITD) increases with age. Apoptosis plays a pivotal role in the regulation of immune mechanisms in the pathogenesis of AITD. There is considerable evidence that FAS and FAS ligand (FASL) interaction is implicated in the pathogenesis of autoimmune disorders $(13,14)$. Mysliwiec et al. (15) found positive correlations between sFAS and age in GD patients. FAS/FASL and BCL2 signaling pathways seem to be age related and may explain, at least in part, the milder course of Graves' disease in elderly patients. Hiromatsu et al. (16) suggest a role of FAS/FASL interaction in the pathogenesis of GD, and their results suggest that the increased expression of FASL in GD thyrocytes, the down-regulation of FAS expression by TSH or possibly by TSH receptor autoantibody, and the overexpression of BCL2, which could render thyrocytes resistant to FASL-mediated elimination, may thus be involved in the pathogenesis of GD. Our studies have confirmed the relationship between the basic pathogenesis of GD and the age at 
Table 3 Association between the CD40 gene polymorphism in patients with Graves' disease (GD) and age at onset.

\begin{tabular}{|c|c|c|c|c|c|}
\hline \multirow{2}{*}{ CD40 } & \multicolumn{2}{|c|}{ Age at onset of GD } & \multirow[t]{2}{*}{$\begin{array}{l}\text { Control subjects } \\
\qquad(N=141)\end{array}$} & \multirow[t]{2}{*}{$\begin{array}{c}\text { GD } \geq 40 \text { years } \\
\text { versus } G D<40 \\
\text { years }\end{array}$} & \multirow[t]{2}{*}{$\begin{array}{c}\mathrm{GD} \geq \mathbf{4 0} \text { years } \\
\text { versus controls }\end{array}$} \\
\hline & $<40$ years $(N=135)$ & $\geq 40$ years $(N=80)$ & & & \\
\hline TT & $12(8.90 \%)$ & $13(16.2 \%)$ & $15(10.6 \%)$ & $\chi^{2}=6.168$ & $\chi^{2}=2.979$ \\
\hline CT & $69(51.1 \%)$ & $47(58.8 \%)$ & $77(54.6 \%)$ & $\stackrel{\tilde{P}}{P}=0.046$ & $\stackrel{\widetilde{P}}{P}=0.225$ \\
\hline $\mathrm{CC}$ & $54(40.0 \%)$ & $20(25.0 \%)$ & $49(34.8 \%)$ & & \\
\hline $\mathrm{TT}+\mathrm{CT}$ & $81(60.0 \%)$ & $60(75.0 \%)$ & $92(65.2 \%)$ & $\chi^{2}=5.007$ & $\chi^{2}=2.260$ \\
\hline $\mathrm{CC}$ & $54(40.0 \%)$ & $20(25.0 \%)$ & $49(34.8 \%)$ & $\hat{P}=0.025$ & $\stackrel{\tilde{P}}{=}=0.174$ \\
\hline & & & & 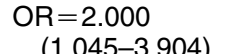 & $\begin{array}{l}\mathrm{OR}=1.598 \\
(0.834-3.125)\end{array}$ \\
\hline \multicolumn{6}{|l|}{ Allele } \\
\hline $\mathrm{T}$ & $93(34.4 \%)$ & $73(45.6 \%)$ & $107(37.9 \%)$ & $\chi^{2}=5.299$ & $\chi^{2}=2.495$ \\
\hline C & $177(65.6 \%)$ & $87(54.4 \%)$ & $175(62.1 \%)$ & $\widetilde{P}=0.021$ & $\widetilde{P}=0.114$ \\
\hline & & & & $\begin{array}{l}\mathrm{OR}=1.597 \\
\quad(1.049-2.428)\end{array}$ & $\begin{array}{l}\mathrm{OR}=1.372 \\
(0.908-2.072)\end{array}$ \\
\hline
\end{tabular}

onset of GD, which is known to be associated with an increased risk for Hashimoto thyroiditis (17). This study further demonstrated a relationship between the age at onset of $\mathrm{GD}$ and the $\mathrm{T} / \mathrm{T}$ genotype in the $\mathrm{CD} 40$ gene and the exon $10 \mathrm{~T} / \mathrm{T}$ genotype in the $\mathrm{TG}$ gene.

In the previous studies, the associations between age at onset and different HLA genotypes in Caucasians (18), and Japanese (19), and ICAM-1 gene alleles in Caucasians (20) and CD4O genotypes in Japanese (21), have been reported. Therefore, we evaluated the differences between the frequencies of the $C D 40$ and $T G$ genotypes in Taiwanese patients with GD onset aged below 40 years and those with a later onset of GD. Our study group showed that there are two peaks in the distribution of age at onset of GD. The results suggest that at least two factors may influence GD susceptibility; however, we emphasized that age at onset of GD should be considered in the analysis. No studies to date have examined the association between the age at GD onset and $C D 4 O$ and $T G$ genotypes in Taiwanese patients. In addition, we wondered whether the age at GD onset may influence the thyroid autoimmunity of GD across populations of different ethnic backgrounds.
The TG gene may cause a predisposition to GD by the mechanisms of sequence changes in $T G$ may change its antigenicity making it more immunogenic (22). E10 SNP158 is a silent SNP (i.e., it does not cause an amino acid substitution). The E12 SNP has been identified as causing an amino acid substitution (Val to Met). The change from a nonpolar amino acid (Val) to a nonpolar amino acid (Met) would not be expected to change the structure of $T G$ in this region. The E33 SNP has been identified as causing a nonconservative amino acid substitution (Trp to Arg), and the change from a hydrophobic amino acid (Trp) to a positively charged hydrophilic amino acid (Arg) would be expected to change the structure of $T G$ at this region; however, the precise mechanism for the pathogenesis of this disorder is not fully understood. GD most likely develops as a consequence of a complex interaction between genetic susceptibility and environmental effects.

In conclusion, the frequency of the TT genotype at the CD4O SNP showed a significant increase in GD patients who developed GD aged above 40 years when compared with those below 40 years in a Taiwanese population. In addition, we performed case control association analysis

Table 4 Association between the TG gene E10 polymorphism in patients with Graves' disease and age at onset.

\begin{tabular}{|c|c|c|c|c|c|}
\hline \multirow{2}{*}{$\frac{\text { E10 }}{\text { Genotype }}$} & \multicolumn{2}{|c|}{ Age at onset of GD } & \multirow[t]{2}{*}{$\begin{array}{c}\text { Control subjects } \\
(N=141)\end{array}$} & \multirow[t]{2}{*}{$\begin{array}{c}\mathrm{GD} \geq \mathbf{4 0} \text { years } \\
\text { versus } \mathrm{GD}<\mathbf{4 0} \text { years }\end{array}$} & \multirow[t]{2}{*}{$\begin{array}{l}\mathrm{GD} \geq 40 \text { years } \\
\text { versus controls }\end{array}$} \\
\hline & $<40$ years $(N=135)$ & $\geq 40$ years $(N=80)$ & & & \\
\hline TT & $8(5.9 \%)$ & $10(12.5 \%)$ & $15(10.6 \%)$ & $\chi^{2}=2.972$ & $\chi^{2}=0.582$ \\
\hline $\mathrm{TC}$ & $80(59.3 \%)$ & $46(57.5 \%)$ & $77(54.6 \%)$ & $\stackrel{P}{P}=0.226$ & $\widetilde{P}=0.748$ \\
\hline $\mathrm{CC}$ & 47 (34.8\%) & $24(30.0 \%)$ & $49(34.8 \%)$ & & \\
\hline $\mathrm{TT}+\mathrm{TC}$ & $88(65.2 \%)$ & $56(70.0 \%)$ & $125(88.7 \%)$ & $\chi^{2}=0.530$ & $\chi^{2}=11.979$ \\
\hline \multirow[t]{3}{*}{$\mathrm{CC}$} & $47(34.8 \%)$ & $24(30.0 \%)$ & 16 (11.3\%) & $\widetilde{P}=0.470$ & $P=0.001$ \\
\hline & & & & $\mathrm{OR}=1.246$ & $\mathrm{OR}=0.229$ \\
\hline & & & & (0.662-2.376) & $(0.137-0.641)$ \\
\hline $\mathrm{T}$ & \\
\hline \multirow{4}{*}{ C } & $90(35.0 \%)$ & $66(41.3 \%)$ & 107 (37.9\%) & $\chi^{2}=1.387$ & $\chi^{2}=0.469$ \\
\hline & $174(64.4 \%)$ & $94(58.7 \%)$ & $175(62.1 \%)$ & $P=0.239$ & $P=0.494$ \\
\hline & & & & $\mathrm{OR}=1.273$ & $\mathrm{OR}=1.148$ \\
\hline & & & & (0.834-1.938) & (0.757-1.738) \\
\hline
\end{tabular}


of the TG SNPs in combination with the CD4O SNPs, which showed no evidence of an interaction between the CD4O and TG E10 SNPs. These findings suggest the obvious differences in the genetic backgrounds of the GD patients in the early-onset and late-onset groups. The CD4O gene may play an important role in the immunogenetic pathogenesis of late-onset GD, and the TT genotype is likely to be associated with late-onset Taiwanese patients.

\section{Declaration of interest}

There is no conflict of interest that could be perceived as prejudicing the impartiality of the research reported.

\section{Funding}

This research did not receive any specific grant from any funding agency in the public, commercial or not-for-profit sector.

\section{Acknowledgements}

We thank all of the GD and control patients who graciously agreed to participate in this study. We also thank Hsu-Huei Weng, M D and the Statistical Analysis Laboratory, Department of Medical Research, Kaohsiung Medical University Hospital, Kaohsiung Medical University for statistical assistance. This clinical trial has been registered at Institutional Review Board of Kaohsiung Medical University Hospital. (KMUH-IRB-960130).

\section{References}

1 Weetman AP. Graves' disease. New England Journal of Medicine $20003431236-1248$.

2 Allahabadia A, Heward JM, Nithiyananthan R, Gibson SM, Reuser TT \& Gough SC. MHC class II region, CTLA4 and ophthalmopathy in patients with Graves' disease. Lancet 2001 358 984-985.

3 Kamijo K. TSH-receptor antibody measurement in patients with various thyrotoxicosis and Hashimoto's thyroiditis: a comparison of two two-step assays, coated plate ELISA using porcine TSHreceptor and coated tube radioassay using human recombinant TSH-receptor. Endocrine Journal 200350 113-116.

4 Stenszky V, Kozma L, Balázs C, Rochlitz S, Bear JC \& Farid NR. The genetics of Graves' disease: HLA and disease susceptibility. Journal of Clinical Endocrinology and Metabolism 198561 735-740.

5 Tomer Y, Concepcion E \& Greenberg DA. A C/T single nucleotide polymorphism in the region of the CD40 gene is associated with Graves' disease. Thyroid 200212 1129-1135.

6 Kim TY, Park YJ, Hwang JK, Song JY, Park KS, Cho BY \& Park DJ. A $\mathrm{C} / \mathrm{T}$ polymorphism in the $5^{\prime}$-untranslated region of the $\mathrm{CD} 40$ gene is associated with Graves' disease in Koreans. Thyroid 200313 919-925.

7 Houston FA, Wilson V, Jennings CE, Owen CJ, Donaldson P, Perros P \& Pearce SH. Role of the CD40 locus in Graves' disease. Thyroid 200414 506-509.
8 Heward JM, Simmonds MJ, Carr-Smith J, Foxall H, Franklyn JA \& Gough SC. A single nucleotide polymorphism in the CD40 gene on chromosome 20q (GD-2) provides no evidence for susceptibility to Graves' disease in UK Caucasians. Clinical Endocrinology 200461 269-272.

9 Hsiao JY, Hsieh MC, Tien KJ, Hsu SC, Shin SJ \& Lin SR. Association between a C/T polymorphism in exon 33 of the thyroglobulin gene is associated with relapse of Graves' hyperthyroidism after antithyroid withdrawal in Taiwanese. Journal of Clinical Endocrinology and Metabolism 200792 3197-3201.

10 Ban Y, Greenberg DA, Concepcion E, Skrabanek L, Villanueva R \& Tomer Y. Amino acid substitutions in the thyroglobulin gene are associated with susceptibility to human and murine autoimmune thyroid disease. PNAS $200310015119-15124$.

11 Onuma H, Ota M, Sugenoya A \& Inoko H. Association of HLADPB*0501 with early-onset Graves' disease in Japanese. Human Immunology 199439 195-201.

12 Lavard L, Madsen HO, Perrild H, Jacobsen BB \& Svejgaard A. HLA class II associations in juvenile Graves' disease: indication of a strong protective role of the RB1*0701,DQA1*0201 haplotype. Tissue Antigens 199750 639-641.

13 Nagata S \& Golstein P. The Fas death factor. Science 1995267 1449-1456.

14 Thompson CB. Apoptosis in the pathogenesis and treatment of disease. Science 1995267 1456-1462.

15 Myśliwiec J, Okłota M, Nikołajuk A \& Górska M. Age related changes of soluble Fas, Fas ligand and Bcl-2 in autoimmune thyroid diseases. Endokrynologia Polska 200758 492-495.

16 Hiromatsu Y, Hoshino T, Yagita H, Koga M, Sakisaka S, Honda J, Yang D, Kayagaki N, Okumura K \& Nonaka K. Functional Fas ligand expression in thyrocytes from patients with Graves' disease. Journal of Clinical Endocrinology and Metabolism $1999 \mathbf{8 4} 2896-$ 2902.

17 Kotani T, Aratake Y, Hirai K, Fukazawa Y, Sato H \& Ohtaki S. Apoptosis in thyroid tissue from patients with Hashimoto's thyroiditis. Autoimmunity 199520 231-236.

18 Chen QY, Huang W, She JX, Baxter F, Volpe R \& Maclaren NK. HLA-DRB ${ }^{*} 08$, DRB ${ }^{*} 03 /$ DRB $^{*} 0101$, and DRB*0202 are susceptibility genes for Graves' disease in North American Caucasians, whereas DRB $1 * 07$ is protective. Journal of Clinical Endocrinology and Metabolism 199984 3182-3186.

19 Onuma H, Ota M, Sugenoya A \& Inoko H. Association of HLADPB $1 * 0501$ with early-onset Graves' disease in Japanese. Human Immunology 199439 195-201.

20 Kretowski A, Wawrusiewicz N, Mironczuk K, Mysliwiec J, Kretowska M \& Kinalska I. Intercellular adhesion molecule 1 gene polymorphisms in Graves' disease. Journal of Clinical Endocrinology and Metabolism $2003 \mathbf{8 8} 4945-4949$.

21 Tokunori M, Yuji H, Tomoka F, Michiko I, Hiroo K, Ikuyo M \& Kentaro Y. A C/T polymorphism in the $5^{\prime}$ untranslated region of the CD40 gene is associated with later onset of Graves' disease in Japanese. Endocrine Journal 200552 471-477.

22 Saegusa K, Ishimaru N, Yanagi K, Arakaki R, Ogawa K, Saito I, Katunuma N \& Hayashi Y. Cathepsin S inhibitor prevents autoantigen presentation and autoimmunity. Journal of Clinical Investigation $2002110361-369$.

Received 31 July 2008

Accepted 18 August 2008 